\title{
MRI装置のQCと施設間比較を対象とした性能評価法の構築
}

\author{
小倉明夫 - 東田満治 ${ }^{1)} \cdot$ 山崎 勝1) 井上博志 ${ }^{2)} \cdot$ 石黑秋弘 $^{3)}$
}

\author{
京都市立病院放射線科 \\ 1 ) 大阪市立大学医学部附属病院中央放射線部 \\ 2)洛和会音羽病院放射線部 \\ 3)大阪府立母子医療センタ一放射線科
}

緒 言

磁気共鳴画像装置(以下，MRI装置)の性能評洒法の プロトコルとしては, 諸外国の研究機関から, 数種の 報告がなされている，代表的なところでは，NEMA Standards (National Electrical Manufactures Association Standards：以下, NEMA基準(-4)', American Association of Physists in MedicineのReports of AAPM nuclear magnetic resonance Task Group No.1 (以下, AAPM報告-5.61)，European Economic CommunityのRe- search Projectの報告7.8)等がある。これらは，装置メ 一カのシステムの性能仕様(装置の性能に関する仕様) を対象とするもの，あるいは，日常の品質管理を目的 とするものと様々であるが，その評価法にほとんど大 差はない.

しかしながら，これらの方法は，われわれユーザが 日常点検の目的や施設間の差を評価する目的で用いる には，手法が煩雑であったり，測定の際に制限がある 等，多くの問題が存在する。 そのため，われわれはユ

\section{Performance Evaluation by Means of Quality Control of MRI System and Comparison of Institutions}

\section{AKIO OgURA, MITSUJI HIGASHIDA, ") MASARU YAMAZAKI, ') HIROSHI INOUE, ${ }^{2)}$ and AKIHIRO ISHIGURO ${ }^{3}$}

Department of Radiology, Kyoto City Hospital

1 ) Department of Radiology. Osaka City University Hospital

2)Department of Radiology, Otowa Hospital

3) Department of Radiology, Osaka Medical Center \& Research Institute for Maternal \& Child Health

Received June 21, 1999; Revision accepted Feb. 5, 2000; Code No. 261

\section{Summary}

To evaluate the performance of clinical magnetic resonance imaging systems, standard test procedures have been recommended by the NEMA, AAPM task group, EEC concerted research project, and others. The purpose of these standard tests is to determine system performance specifications, reference procedures for test acceptance, and periodic examination of quality control. However, the recommended measurements are very complicated when used for periodic quality control checks or comparisons with other systems. Therefore, we determined new standard test procedures that serve these purposes. Eleven clinical MRI systems in nine clinical facilities were evaluated using these new standard test sets. Results indicated that the measurement time was too short using the new test sets. However, through comparison with various MRI systems, the specificity of each system could be determined.

Key words: Quality control, Slice thickness, Contrast-to-noise ratio (CNR), Magnetic resonance imaging (MRI) 
Table SE imaging parameters for evaluating the performance of MRI systems.

\begin{tabular}{c|c|c|c|c|c|c}
\hline \hline & TR (msec) & TE $(\mathrm{msec})$ & NEX & FOV $(\mathrm{mm})$ & Slice thickness $(\mathrm{mm})$ & Matrix \\
\hline SNR & 2800 & $15-20$ & 1 & 250 & 8 & $256 \times 256$ \\
Uniformity & 2800 & $15-20$ & 1 & 250 & 8 & $256 \times 256$ \\
Slice thickness & 2800 & $15-20$ & 1 & 200 & 3 & $128 \times 128$ \\
Distortion & 300 & $15-20$ & 5 & 256 & 8 & $512 \times 512$ \\
CNR-1 & 2000 & 90 & 1 & 250 & 8 & $256 \times 256$ \\
CNR-2 & 500 & $15-20$ & 3 & 250 & 8 & $256 \times 256$ \\
\hline
\end{tabular}

一ザサイドに立った，われわれの目的に合致する性能 評価法の構築を行い，その評価法によって，各施設同 一ファントムを巡回し，評価を行った。

本著においては，それらの性能評価法の紹介と，施設 間の性能評価值の比較から得た若干の知見を報告する。

\section{1. 性能評価項目}

性能評価項目としては，NEMA基準，AAPM報告を 参考とし，以下に示す 5 項目とした。

(1) 信号雑音比 (signal-to-noise ratio：以下, SNR)

(2)均一性

(3) スライス厚

(4) 二次元的幾何学的歪

（5）コントラスト雑音比 (contrast to noise ratio：以 下, CNR)

\section{2. 便用ファントム}

評価用ファントムとして, 日石式PVAゲル封入ファ ントム90-401型(以下，PVAファントム：日興フアイ ンズ工業株式会社製)を使用した。このファントムの 使用理由は，導電率が人体と等価であること，またQ 值やプロトン密度， $T_{1}$ 值， $T_{2}$ 值が人体と等価であるこ と，経時的に安定していること等によるが，同様の特 性を有するファントムであれば他のものでも問題ない と考える9,10).ただし，ファントム内容物によりMR信 号が異なるため，QC目的や装置間，施設間の比較に おいては，経時的変化のない，同一のファントムを使 用すべきである。

AAPM報告では施設間の比較においては，同一のファ ントムを使用しても，比較不能と提議している．しか し，われわれは同一ファントムを使用し，施設間，装置 間の特性を評価した。これは，各装置の絶対的な評価は 行えないとしても，相対的な比較により各装置の特性を 検討できる可能性があると考えたためである.

\section{3. 㗉性能伻価法}

\section{3-1 信号雑音比 (SNR)}

PVAファントムをRF受信コイルの中心に置き，
Tableに示す撮像条件によって, head coil とbody coil で，それぞれ横断像の撮像を行う.

なお撮像は, 1 回目目の撮像後 5 分以内に, 同一条 件で 2 回目の撮像を行い，画像を 2 枚作成する， 1 回

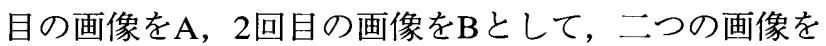
サブトラクションした像に $16 \mathrm{~cm} \phi$ のROIを設定し，そ のROI内の信号の標準偏差 $(\mathrm{SD})$ を $S D$ とする．同様に 1 回目の像にも同上のROIを設定し, ROI内の平均ピ クセル值をSとする.SNR(サブトラクション法)は下 式で算出を行う。

$$
S N R=\sqrt{2} \cdot S / S D
$$

ここで，サブトラクション処理は，各装置に付属の 処理機能を用いて行うことが一般的であるが，装置に よっては，サブトラクション処理を有しないものや， サブトラクション処理において，マイナス值を 0 に置 き換える装置が存在する。これは，これらの付属機能 が臨床画像の処理を目的とするため，マイナス值の表 示をする臨床的意義がないことに起因するが，SNRの 実験をする場合には誤測定の原因となる.

このサブトラクション処理機能の有無を検証する方 法として, A画像一B画像のサブトラクション画像の $\mathrm{SD}$ と画像一 $\mathrm{A}$ 画像のサブトラクション画像のSDが同 一であることを確認する。これらが異なる值を示す場 合は，サブトラクション画像のSDは以下の数式より 算出できる.

$$
S D_{\mathrm{SAB}}=\sqrt{S D_{\mathrm{A} \cdot \mathrm{B}}{ }^{2}+S D_{\mathrm{B} \cdot \mathrm{A}^{2}}}
$$

ただし， $S D_{\mathrm{A}-\mathrm{B}}$ は，画像 $\mathrm{A}-\mathrm{B}$ のサブトラクション像の $\mathrm{SD}, S D_{\mathrm{B}-\mathrm{A}}$ は, 画像B一Aのサブトラクション像の $\mathrm{SD}$ を示す.

\section{3-2 均一性}

SNR評価と同様の撮像条件 (Table)において, PVA ファントムをhead coilでは横断像, body coilでは横断 像と矢状断像を撮像する．各画像から，われわれが構 
uniformity index

$U(C)=(S(C)-S(W)) / S(W)$ $U(R)=(S(R)-S(W)) / S(W)$ $\mathrm{U}(\mathrm{L})=(\mathrm{S}(\mathrm{L})-\mathrm{S}(\mathrm{W})) / \mathrm{S}(\mathrm{W})$ $U(O)=(S(O)-S(W)) / S(W)$ $U(U)=(S(U)-S(W)) / S(W)$

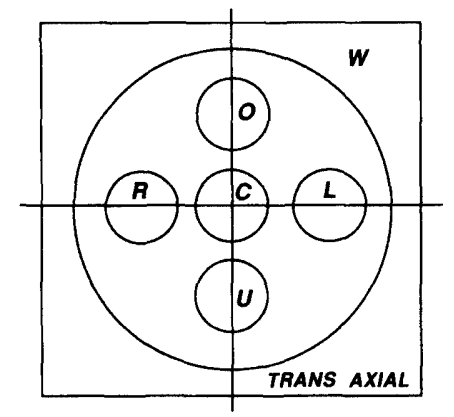

Fig. 1 Schema of the position of ROI for calculating uniformity.

築した均一性評価法(区分法)によって，局所均一性お よび総合均一性の評価を行う。

区分法"1は，局所不均一分布を簡便に把握与る手法 である. Fig. 1 に示すように，撮像ファントム像内に 最大径の $90 \%$ の直径のROIを設定し，その平均ピクセ ル值を $S(W)$ とする。その大きなROIの中に $25 \%$ の小 さなROIを上下左右中心にそれぞれ 5 力所設定し，そ の平均ピクセル值を, $S(O), S(U), S(R), S(L), S(C)$ とする．各小さなROIの平均ピクセル值と大きなROI の平均ピクセル值 $S(W)$ の差を $S(W)$ で除した值を局所 均一性Uのindexとする。

たとえば，局所均一性 $U(O)$ は，

$$
U(O)=(S(O)-S(W)) / S(W)
$$

で示される.

また，総合均一性は，各局所均一性より以下の式に よって算出する.

$$
U=\sqrt{\left(U(C)^{2}+U(R)^{2}+U(L)^{2}+U(O)^{2}+U(U)^{2}\right) / 5}
$$

\section{3-3 スライス厚}

Tableに示す撮像条件によって, PVAファントムの ウエッジファントムを撮像し，われわれが構築した partial volume effectを用いた方法 ${ }^{22}$ (以下，PVE法)に よりスライス厚の測定を行う。PVE法は，スライスプ ロファイルからFWHMを測定するのではなく，異な るスライス位置の 4 枚の画像の同位置のROI内の平均 ピクセル值から，スライス厚を算出する手法で，非常 に簡便である。

PVE法は，Fig. 2に示すような隣接した二つの異な るMR信号を有するファントムに扔いて，任意のスラ イス内に，ファントムAのみを含む場合と，ファント ム $\mathrm{B}$ のを含む場合，そして，スライス内にファント

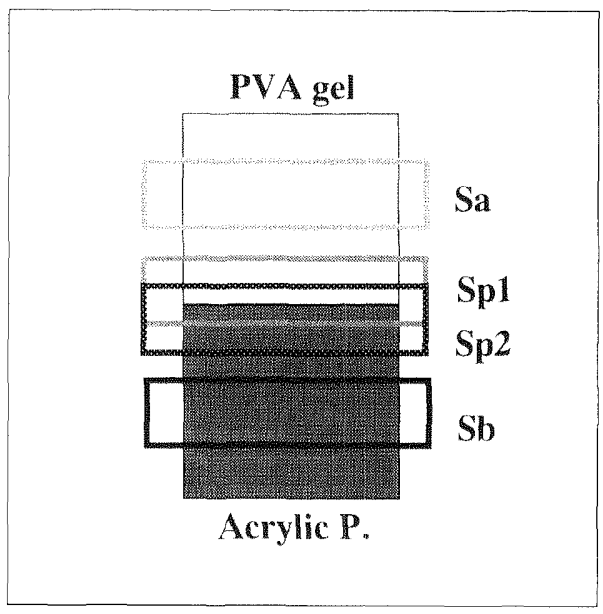

Fig. 2 Schema of the slice position in the PVE method of evaluating slice thickness.

ム $\mathrm{A}$ と Bを両者含む場合を，含む率を変化させて 2 回，合計 4 回撮像する。スライス位置の設定は, Fig. 2 のような位置決め画像を参照し，オフセット值を入力 することにより行う。それぞれのスライス像内にFig. 3 に示すようなROIを 3 力所設定し，三つのROI内の平 均ピクセル值を求める。ファントムAのみを含むスラ イス像の平均ピクセル值を $S a$ ，ファントム むスライス像の平均ピクセル值を $S b$, ファントムA Bをパーシャルに含むスライス像の平均ピクセル值を $S p 1 ， S p 2$ とすると，スライス厚 $S$ は, 以下の数式によ って算出できる。

$$
S=d(S a-S b) /(S p 1-S p 2)
$$

ただし，dは，ファントムAとBをパーシャルに含むス ライス中心間の距離である.

ここで，この手法の重要なポイントは，MRI信号の 異なる二つのファントムをパーシャルに含むスライス 内の信号が，ファントムの隣接面とスライスの中心位 置のズレに対し，直線性があるという前提が成り立っ ていることである。すなわちこれは，スライス面がフ アントム面と平行になっているというアライメントに 依存する。したがって，この実験を行う前には，Fig. 3 に示す三つのROI内の信号值に差がないか，またスラ

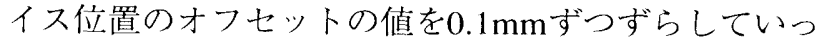
た場合，信号值に直線性があるかを確認しておく必要 がある。

\section{3-4 二次元的幾何学的歪}

PVAファントムのピンセクション部を用い, Table に示す撮像条件によって横断像を撮像する。

Fig. 4 に示すピンセクションのAからHそれぞれの 


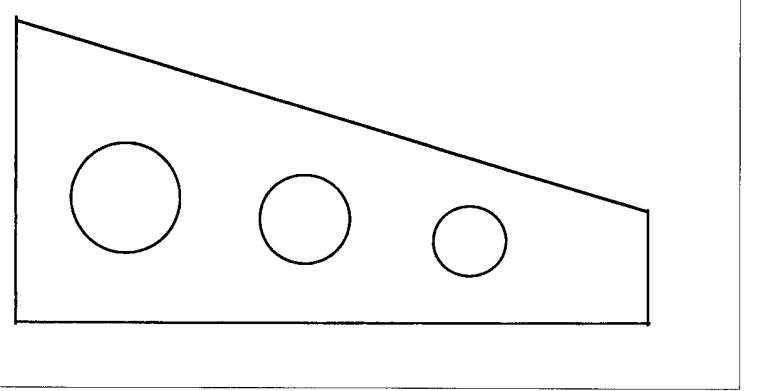

Fig. 3 Schema of the position of ROI in the PVE method of evaluating slice thickness.

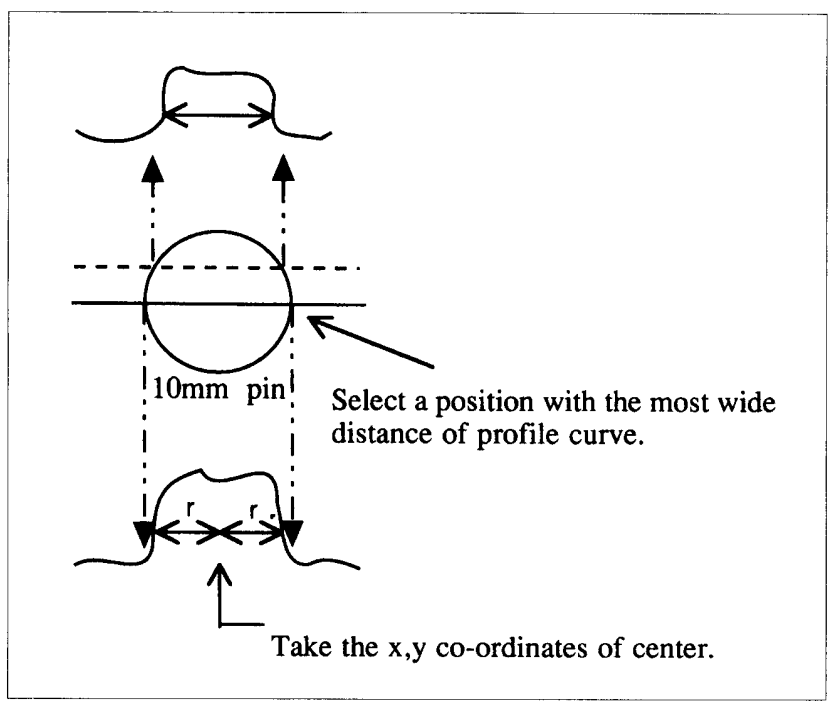

Fig. 5 Diagram of how to determine the center with the pin section.

ピン中心のディスプレイ上のXY座標を求める。座標 の求め方は, 目的ピン上に数本のプロファイルカーブ を描き，幅の最も広いプロファイルカーブの中心のデ イスプレイ上のXY座標を読み取る(Fig. 5)。AB間, CD間，EF間，GH間，EG間，HF間，EH間，GF間の 距離を各ピン中心のXY座標からピタゴラスの定理を 用いて算出した。たとえば，ピンAの中心が $X a ， Y a$ で，Bの中心が $X b, Y b$ ならは，距離 $A B$ 間は，

$$
A B=\sqrt{(X a-X b)^{2}+(Y a-Y b)^{2}}
$$

で示される。

歪み率は，以下の式において算出した。

歪み率\% $=[($ 真の距離 - 画像上の距離 $) /$ 真の距離 $]$ $\times 100$

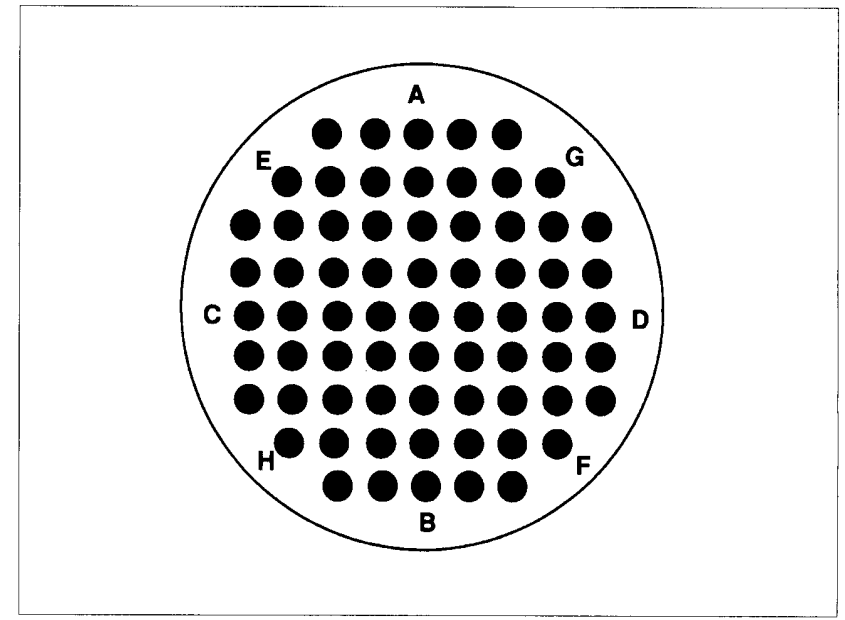

Fig. 4 Schema of the pin section for measuring image distortion.

\section{3-5 コントラスト雑音比 (CNR)}

PVAファントムのコントラストセクションを用い, Tableに示す二つの撮像法によって横断像を撮像し た。コントラストセクションには，あらかじめ含水率 の異なるPVAゲル $(76,78,80 \%)$ を封入した円筒が 3 本と, 常磁性体イオン $\left(\mathrm{Gd}^{3+}\right)$ の混入量が異なるPVAゲ ル (含水率はすべて $82 \%, \mathrm{Gd}^{3+}$ 濃度は $0.1,0.2$, $0.3 \mathrm{mmol}$ )を封入した问简が 3 本埋め込まれている. 撮像後の画像から，これら六つの円筒部内にROIを設 定し, ROI内の平均ピクセル值からCNRを測定する。 CNR測定法は文献13)に示西沢らの評価法を用い た. 数式を以下に示す。

$$
\begin{aligned}
& C N R=(G V C / A L V)^{1 / 2} \\
& G V C=\Sigma(\mu i-\Sigma \mu i / N)^{2} / N \\
& A L V=\Sigma \sigma i^{2} / N
\end{aligned}
$$

ただし，Nはコントラスト資料数， $\mu i, \sigma i(i=1,2, \ldots \ldots$. N)は各コントラスト資料のROI内のピクセル值の平均 值と分散を示す。この評価法の有用性は文献14)に示 されている。

\section{4. 施設間，装圈間評価}

同一ファントムを，各施設持ち回り，Tableに示す 撮像条件で，上記評洒法による性能評価を，9施設11 機種により行った。

スライス厚測定の実験に执いて，スライス厚は $3 \mathrm{~mm}$ ，パーシャルのスライス中心シフト距離は $1.5 \mathrm{~mm}$ と限定したままた，SNRおよび均一性評価はhead coil とbody coilの両者で，スライス厚とCNR評価はhead coilのみで, 幾何学的歪の評価はbody coilのみで測定 を行った。 


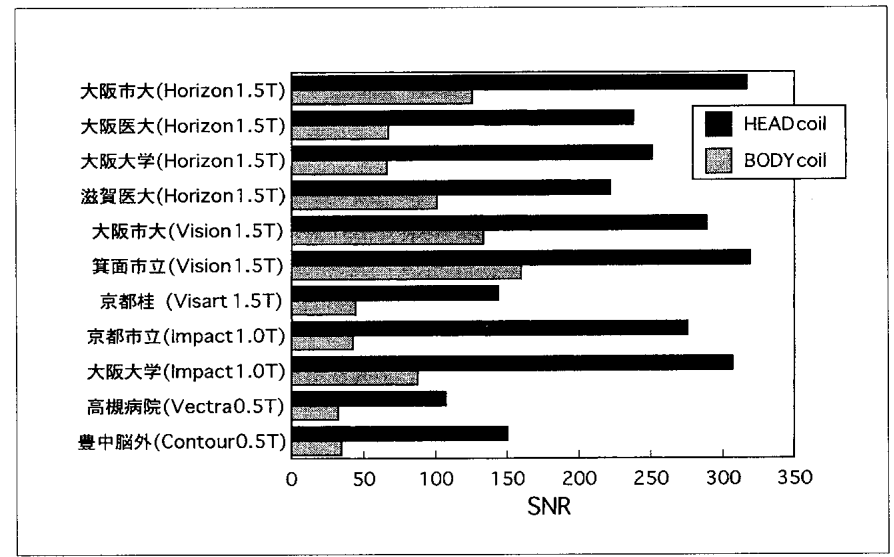

Fig. 6 SNR values of various MRI systems.

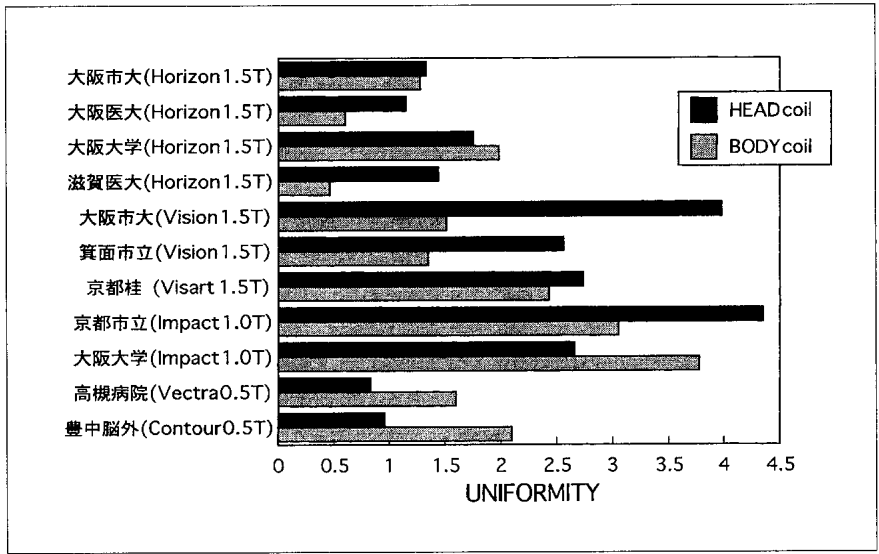

Fig. 7 Uniformities of various MRI systems. The value is large for non-uniformity.
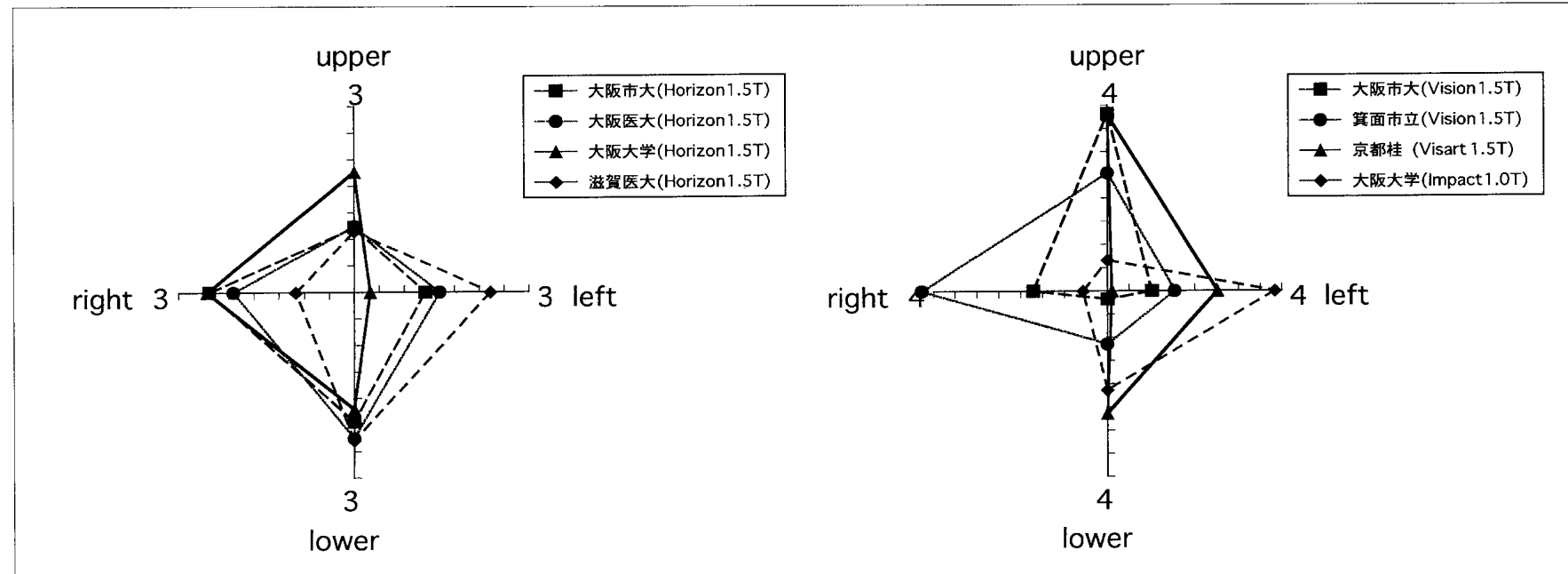

Fig. 8 Local uniformity in the magnet coil.

\section{5. 結 果}

\section{5-1 信号雑音比}

Fig. 6 に各施設，各装置のSNRの結果を示した。同 一機種においても，設置している施設によりSNRが異 なる結果となった。また，head coilとbody coilの比較 に関しては，すべての機種，施設においてhead coilの

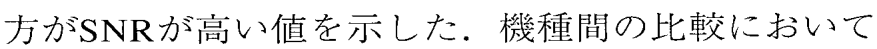
は，有意な特性はみられなかった。

ここで本来，装置性能比較の目的においては，撮像 シーケンスのバンド幅を統一すべきであるが，一般的 にはユーザの設定領域外のため，可能な限り近い設定 条件で比較を行った。

\section{5-2 均一性}

Fig. 7 に各施設，各装置の総合均一性を，Fig. 8 に 局所均一性の結果を示した。総合均一性に関して，わ れわれのデータでは，GE社のHorizon1.5Tのhead coil の均一度が他装置に比べ，優良な傾向を示した。それ

以外は，特に装置の特異性は見られず，同種装置にお いても，施設間で值は異なった。また，局所均一性に 掞いても，不均一分布は装置，施設間での特異性はみ られなかった。

\section{5-3 スライス厚}

$3 \mathrm{~mm}$ の設定スライス厚に対し，ほとんどの装置が, $3 \mathrm{~mm}$ 上回る值を示したが，その誤差は最大でも 15 \%以内であり，3 $\mathrm{mm}$ 以下の值を示す施設も存在した (Fig. 9).

\section{5-4 二次元的幾何学的歪測定}

歪みに関しては, すべての施設, 装置において, 歪 み率が $\pm 0.5 \%$ 以内で良好な結果を示した $($ Fig. 10).

\section{5-5 コントラスト雑音比(CNR)}

CNRに関しては，当然ながら静磁場強度が変化すれ ば，T緩和の差によりコントラストも変化する。しか 


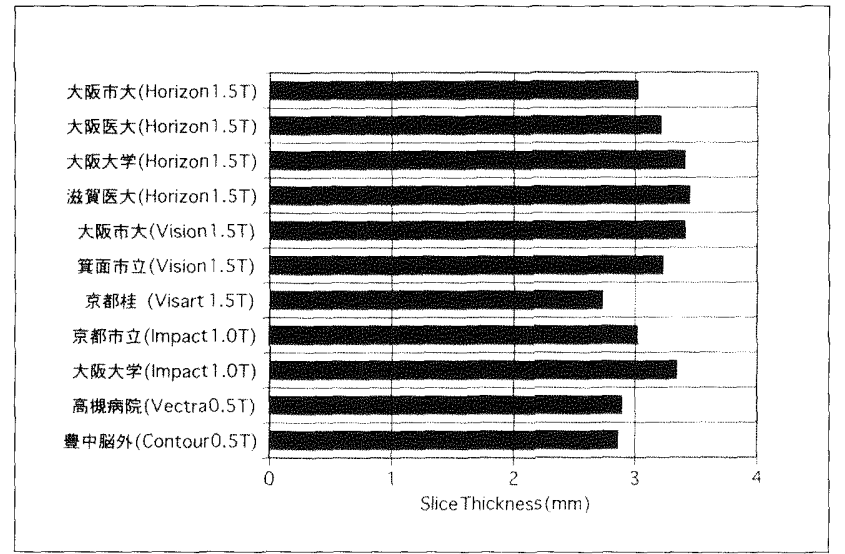

Fig. 9 Slice thickness of various MRI systems.

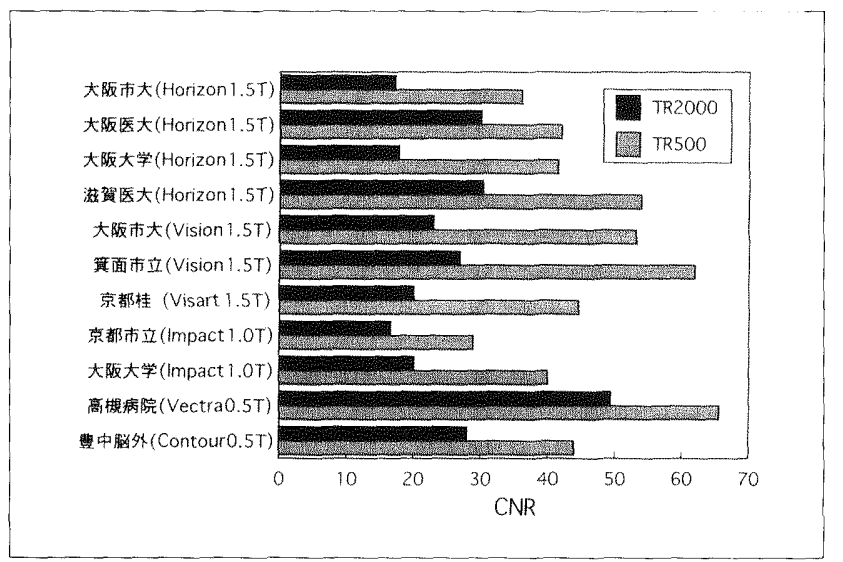

Fig. 11 CNR of various MRI systems.

し，同種装置においいても，CNRの值のバラッキがみら れた(Fig. 11)。CNRは，コントラスト成分のみを評洒 するのではなく，SNRにも依存するため，コントラス ト成分のみを示すGVCを横軸にしたグラフ(Fig. 12)を 提示する. Fig. 12より，コントラストのみを考慮した 場合には，同種装置間の差が減少した。

\section{6. 考 富}

MRI装置の性能維持管理は，従来，メーカに任せる ことが多く，ユーザが使用装置の経年的な性能の変化 の把握や，他装置あるいは他施設の同一機種との性能 比較の把握が困難な場合が多い，その原因として性能 評価法に統一性がなく，また手法が煩雑で時間を要す ることが考えられる。

そのため，今回われわれは，それらの目的に合致し た評価法の構築を行い，多施設において性能評価を実 施した。

各施設，装置において定期的な点検を実施し，すべ ての装置の性能が基準值内に保持されているが，今回 の測定では，同種装置に扔いても差がみられた。特

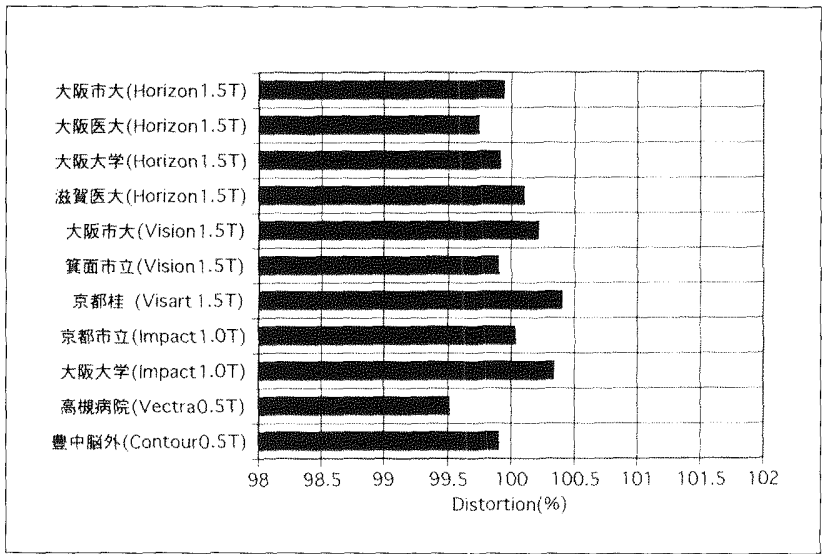

Fig. 10 Distortion of various MRI systems.

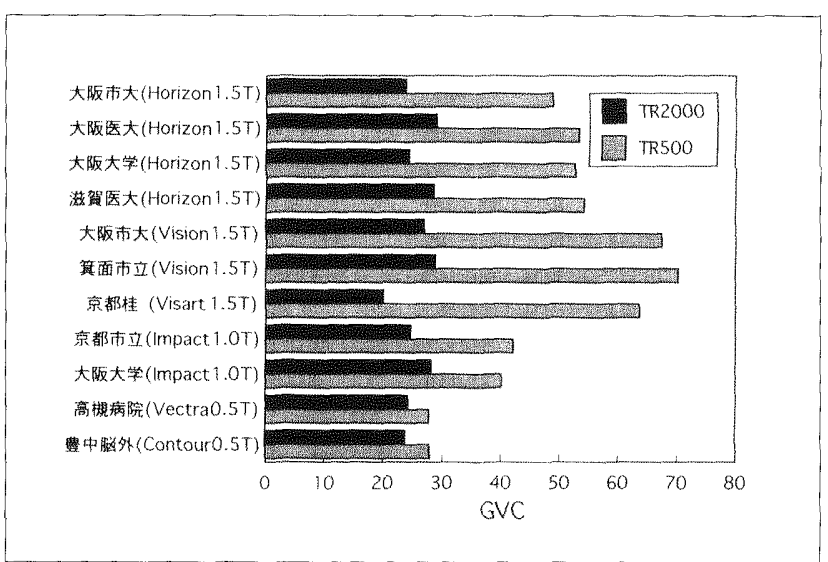

Fig. 12 GVC of various MRI systems. GVC indicates image contrast without the effect of SNR.

に, SNR, CNR，均一性においては，その差が顕著 であった。これらは，特にコイルの性能に依存すると ころが大きい，われわれは，この評洒結果から，再度 メーカに調整を依頼して，指示を行った経験もある。 これらの点からも，各自施設の装置の性能を把握して 扔くことは意義があることと考えられる。

性能評価を定期的に㥶施するためには，測定法が簡 便であることが必須であり，われわれは特にその点に 留意して, 評価法の構築を行った。その結果, 評価に 要する時間は，評価に対する慣れや，個人差もある が，NEMA基準やAAPM報告と比較し，1/5程度に短 縮可能となり，全行程を終了する時間は，1時間程度 であった。また，QCのみを目的とした評洒であれ ば，評洒項目を選択し，さらに評価時間の短縮が可能 であり，今後の課題としたい。

また，メーカ間や装置間の比較に扔いて，今回は顕 著な特性の差は得られなかった。これは, 測定機種数 が少ないためとも考えられるが，メ一力間あるいは機 種間の性能差より, むしろ各施設の装置固有の性能差 が大きいためと考えられた。 
ただし，本来装置性能のみの比較を目的とするなら ば，RF特性を含め，諸条件の統一を行うべきである が，今回の実験においては，ユーザが日常使用する撮 像に対する比較を目的としたため, 装置性能のみの比 較とはいえない。

以上，ユーザが自施設の使用機器の性能特性を把握 しておくことは，重要であり，そのため定期的に性能 評価を実施することが必要と考察する。
鉜 辞

本研究に対し, 日本放射線技術学会近畿部会より研 究助成をいただいた。

また，日石式PVAゲル封入ファントムを快く貸して いただいた，日興フアインズ工業株式会社に感謝いた します。

\section{参考文献}

1) National Electrical Manufactures Association: Determination of signal-to-noise ratio in diagnostic magnetic resonance images. NEMA Standard Publication, MS 1,(1988).

2) National Electrical Manufactures Association: Determination of two-dimensional geometric distortion in diagnostic magnetic resonance Images. NEMA Standard Publication, MS 2, (1988).

3) National Electrical Manufactures Association: Determination of image uniformity in diagnostic magnetic resonance images. NEMA Standard Publication, MS 3, (1988).

4) National Electrical Manufactures Association: Determination of slice thickness in diagnostic magnetic resonance images. NEMA Standard Publication, MS 5,(1988).

5) Price RR, Axel L, Morgan T, et al.: Quality assurance methods and phantoms for MR imaging: Report of AAPM Nuclear Magnetic Resonance Task Group No.1. Med Phys, 17(2), 287295, (1990).

6) Och JG, Clarke GD, Sobol WT, et al.: Acceptance testing of magnetic resonance imaging systems: Report of AAPM Nuclear magnetic resonance Task Group No.6. Med Phys, 19 (1), 217-229, (1992).

7) Report on "Standard methodologies for in vivo studies" approver at the Plenary Workshop organized by F.Podo.Rome. Eurospin Quarterly, 7, 79-111,(1986).

8) EEC Concerted Research Project: Identification and characterization of biological tissues by NMR. Magn Reson Imaging, 6, 198-199, (1988).

9) 南部昌夫：高含水ゴム一医用材料およびNMRファントム 一. NMR医学, 5(2), 85-90, (1985).

10) Mano I and Kobayashi T: PVA gel material for MRI phantoms and applications regarding the $\mathrm{Q}$ factor and effect og field strength. Med Imag Tech, 9(2), 162-167,(1991).

11) 小倉明夫, 井上博志, 東田満治, 他 : 診断用MRI装置に抢 ける新しい画像均一性評価法の構築. 日放技学誌, 53 (12), 1789-1794, (1997).

12) 東田満治, 山崎 勝, 小倉明夫, 他：partial volume effect を用いたMRIのスライス厚測定. 日放技学誌，54(8)，947952, (1998).

13）西沢かな枝, 福田信男, 蜂屋順一, 他：MR画像における コントラスト・ノイズ比(CNR)の評価. 日磁医誌, 8(4), 255-261, (1989).

14）小倉明夫, 東田満治, 山崎 勝, 他：MR画像における各 種CNR算出法と信号検出能の関係. 日放技学誌, 54(6), 778-783, (1998).

Fig. 1 均一性評価におけるROIの位置.

Fig. 2 スライス厚測定のためのPVE法のスライス設定.

Fig. 3 スライス厚測定のためのPVE法のROI設定.

Fig. 4 画像歪 評価のためのピンセクションの眓.

Fig. 5 ピンセクションにおける中心位置の求め方.

Fig. 6 各施設MRI装置のSMR值.

Fig. 7 各施設MRI装置の均一度. 均一度值は，不均一なほど，值が大きい，

Fig. 8 マグネットコイル内の局所均一性.

Fig. 9 各施設MRI装置の実測スライス厚值.

Fig. 10 各施設MRI装置の歪率.

Fig. 11 各施設MRI装置のCNR值.

Fig. 12 各施設MRI装置のGVC值. GVC值は，SNRに依存しないコントラスト特性を示す.

Table 